\title{
TEACHING TRANSLATION: OBJECTIVES AND METHODS
}

\author{
Iryna Kobyakova \\ Sumy State University, Sumy, Ukraine \\ kobyakova@ukr.net \\ Svitlana Shvachko \\ Sumy State University, Sumy, Ukraine \\ shvachko.07@ukr.net
}

\begin{abstract}
The article is focused on the set of items: teaching translation, objectives, exercises and assignments (both wordcentered and text-centered translation), translation analysis. The choice of the items is motivated by the dominant functions of transatology (nominative and communicative). The latter succeed in identification of adequate, congruent, equivalent translation. The article discusses the problems of professional validity, theoretical insertions, textocentric analysis. Gains, achievements, goals and perspective vistas are the highlights herein. The ways of translation adaptation have been outlined, among them are conceptualization, de-focusing, redundancy (language economy). The rendering of the original texts into target ones brings the diversity of the exercises and assignments what is the focus centre of the paper. The paper gives an opportunity to make translation analyses of the original and target texts. Semantic isotopy, textual non-linearity, self-organization, rhisomatic way of arranging textual cohesion and coherence, ramified architectonics and interpretation plurality remain actual, urgent, still unsolved problems in translatology. The major principles are manifested in conceptualization, de-focusing, expanse, redundancy (language economy) specific arrangement.
\end{abstract}

Keywords: adaptation; communication; objectives; syncreta; text; translator; transatology.

Introduction. Translation is closely interwoven with sociolinguistics, contrastive linguistics, with concepts of thinking and cognitive aspects. It is an interlinguistic communication, which presupposes both language and culture encoding and decoding. Communicative intention is realized due to the actualization of major linguistic functions - denotative or referential, expressive or emotional and poetic. Semantic equivalence makes translation work: for contents are prior to the forms, meaning comes to the forefront. One cannot be an interpreter without philology and translation competence. What matters greatly is the preparatory work in the process of would be specialists training. Translators are to develop a wide spectrum of skills in reading, writing, listening, speaking, recalling, fluency, grasping intentions, comprehending situations. New forms in the training process are needed to reach the high quality of translation.

The major strategy of the translators is to comprehend what has been said (including informative and pragmatic values), and render it in another language. This article focuses on working out the teaching criteria style that would complement students' natural inclination towards an adequate learning style and pulling down the barriers to the successful academic performance. Translation works with Nominative and Communicative units. The investigation is aimed at analyzing the peculiarities of interpreting training endozones, as they are. The problem is to cope with various approaches, practical recommendations, to choose appropriate, efficient patterns. But the criteria of complex approach are still weakly defined which makes our topic actual. Thus, the aim of this paper is to investigate the translators' training, consider the peculiarities of interpreting modus of translatology.

Nowadays translation is one of the key topics not only for professionals in the fields of linguistics and education, but also for social, political and economic zones. One of the reasons for the growing importance of philology lies in the fact that the realization of the perlocutionary act demands much effort on the part of an interpreter. The diverse vectors of speech activities, the problems of translation, etiquette, social niceties confront an interpreter. Intentions of a medium are interwoven to serve promotion and maintenance of harmony between people speaking different languages. The crucial task on the part of an interpreter is to meet the requirements of the listeners; to identify the message delivered first in a foreign language (original) and then in a target language. To bring the information to listeners an interpreter is to keep close intentions tactics and strategies.

Method. The complex methods have been involved, in particular, ontognostical syncreta (diad, informative pragmatical integrity). The problem of training a translator was touched in the 
middle of the 20th century. Since then the problem has gradually become actual. In the 20th century, the issue was investigated in the works of V. I. Karaban, R. Arrojo, Ph. Benson, Li. Chamberlain, D. Robinson, An. Pym, M. Shuttleworth, M. Cowie. Nowadays scientists work at researching applied linguistics (Ph. Benson), theory and practice of translation (D. Robinson), investigation of vocabulary (M. Shuttleworth, M. Cowie). At present preference is given to the communicative units - their semantic and pragmatic congruence. Translation as a related science is adherent to Common Linguistics, Implication Theory, Discourse Analysis and Pragmatics. The empiric material has been extracted from the English discourse. Methods applied are complex (componential, discursive and definitive). Translation process works by the principle of Tertium Comparationis.

It goes without saying that an interpreter's attention is to be focused upon the original text (the situation and social minds involved into that). Readjustment of an interpreter swings from stages of the decoding to encoding translation. Components of speech model are speaker, interpreter, listener, situation, code, strategies and tactics. To the forefront of the interpreter's career come certain qualities. The obvious things with an interpreter are knowledge of languages and social thesaurus. An interpreter is supposed to have a university education, extensive knowledge of terms, a broad spectre of objects ranging from atomic energy, legal issues, demographic problems, and the rights of man to the tonnage measurement. An interpreter is to obtain a quick mental grasp what is being said to render it quickly into another language (Shvachko S. O., 2015, p. 7). Bashfulness of stage fright will not do either. Students should do their work with discretion, great presence of mind and psychological grounding. To communicate properly for an interpreter means to transmit a message in a way that will be received and understood by the audience. One should always think of the ways what and how to say it. According to Benson (2013), "As the practice of learner training became more widespread in the 1980s and 1990s it increasingly drew upon insights from research on learning strategies, which aimed to identify the behaviours and strategies used by successful learners and train less successful learners in their use" (p. 12). There are some profitips, which surely make an interpreter's job go easier.

An interpreter is advised to use illustrations, figures, stories, humour in a good taste. One should make the audience comfortable with short words and sentences. Figures and proper names should accurately be pronounced. Advisable for the would-be professionals are some relevant exercises to be done:

- make informal two-way interpreting of the dialogue;

- identify adjustments that have been made in a translation;

- translate the Latin mottos into English and Ukrainian;

- retell the text in the source language;

- make a spontaneous translation of a text;

- categorize the stylistic differences of original and target texts;

- complete proverbs with suitable units;

- make a discourse analysis of a translation unit;

- make translations of particular groups of words, (say, translation metasigns).

Advisable for the would-be professionals are some relevant questions to be answered:

- What is the background of implication?

- To what academic discipline does translation belong?

- What do you understand by the dominant principle of translation?

Exercises and assignments make the training process as the main stream go. They widen an interpreter's thesaurus; promote the background knowledge of grammatical, sociolinguistic and strategic categories. They facilitate an interpreter's cognition of valid procedures concerning text encoding and decoding on both sides. The involved process makes the stable cycle: Text speaker ${ }_{1}>$ Text $_{\text {interpreter }}>>$ Text $_{\text {listener }}>>$ Text $_{\text {speaker }_{2}>\text { Text } \text { listener }_{2}>\text { Interpreter }_{2}-\text { to let }}$ communication go.

Translation text analysis is highly beneficial for the future specialists; it reveals to the trainees how the factors work (social, linguistic, and cultural), how the text is verbalized in its explicit and implicit ways. Some items are suggested by the following list of metalanguage terms: the text under analysis belongs to certain style (newspaper, belles-letter, official, scientific, colloquial); the 
dominant words; they refer to; they make the topic go; the pragmatic aspect is verbalized by special means; the precision words (proper names, numerals) are available.

We can trace some terminological units. While translating one should think of the language system they belong to. The author's intentions should not be neglected either. Attention is being focused on the structure of a text, the stylistic means of source language and target language. Redundancy, abundance and modeling work should validly be done. An interpreter communicates comfortably with people of the other culture provided he is quite at ease with the item.

The effectiveness of translation analysis depends much on an interpreter. Language is the bearer of the liaison with culture means and the certain cast of mind, attitudes, understanding of values. Interpreting is not only an attempt to render the meaning of the words but also to convey the values and the concepts that lie behind what is being said by whichever side.

According to Pym, "If translation and linguistics were married, they would have "issues" (p. 417). "No one doubts that different languages have different ways of saying things: I like you is Me gusts ("to me are likeable you") in Spanish, and if you do not use the transformation well you might finish up declaring love (tequiero) or getting into even deeper trouble" (p. 420).

While comparing the different translations of the same text a reduction of the number of units can easily be revealed. This should be done, however, without violations of the communication tasks. The divergences between correlated texts of written translation can be differentiated into two major groups: the divergences resulting from the full extraction of separate information units which makes $76 \%$; the divergences resulting from synonymous replacement of a sentence or a phrase by a shorter sentence, a word combination which makes $22 \%$. Pym found that "in terms of research, there are some areas in which translation researchers might turn to linguistics in search of models and guidance" (p. 427).

There exist some particular methods of compression:

1. Extracting the segments of the text, which are compensated by extra-linguistic situation.

Cf. President signed a Decree to facilitate development of civil society / Президент підписав Указ про сприяння розвитку громадянського суспільства $\rightarrow$ Президент підписав Указ про сприяння розвитку суспільства.

In this example, the segment "a Decree to facilitate the development of civil society" is a standard way of beginning a speech. The fact of starting declaration itself allows the interpreter to omit the part of the utterance.

We joined the interagency working group on deinstitutionalization and establishment of inclusive education / Ми долучилися до роботи міжвідомчої робочої групи з деінституалізації та впровадження інклюзивної освіти $\rightarrow$ Ми долучилися до міжвідомчої робочої групи 3 інклюзивної освіти. In the example above the extraction of the segment "the interagency working group on deinstitutionalization and establishment of inclusive education" in the text does not violate deep communication intention, the audience is aware of what group that the sentence concerns.

2. Extracting the text segments which duplicate some pieces of information:

The above mentioned agreement provides for the establishment of the NATO mission to Ukraine that will include the NATO Liaison Office and the NATO Information and Documentation Centre. The new diplomatic institution and its staff shall enjoy privileges, immunities and assistance provided for the diplomatic missions pursuant to the Vienna Convention on Diplomatic Relations of 1961 / Зазначена Угода передбачає заснування Представництва НАТО в Україні, яке складатиметься з Офісу зв'язку НАТО й Центру інформації та документації НАТО. Нова дипломатична установа та ії персонал отримає привілеї, імунітети та сприяння, що надаються дипмісіям відповідно до Віденської конвенції про дипломатичні зносини 1961 року $\rightarrow$ Зазначена Угода передбачає заснування Представництва НАТО в Україні. Нова дипломатична установа отримає привілеї, імунітети та сприяння, що надаються дипмісіям відповідно до Віденської конвенції про дипломатичні зносини 1961 року.

Such repetitions and parallelisms are common, so this method of speech compression is widely used at present.

3. Extracting the segments, which are regarded as polite patterns, deviations, some epithets, etc. (Rarely numerical data can be avoided otherwise communication will be destroyed). 
The next group of compression is named substitution of a sentence or a phrase by a shorter variant:

The replacement of full name of an organization, state by abbreviation: Cf. Concise Oxford Dictionary - COD, Oxford English Dictionary - OXD. United Nations Educational, Scientific and Cultural Organization - UNESCO. International Criminal Police Organization - INTERPOL. European Space Agency - ESA.

Discussion. Speech compression is a result of current limitations and parallel substitutes. The extent of compression is determined by the need to retain moderate speech of an interpreter. The methods of speech compression are the adjustment devices of translation activities in the particular circumstances. Speech compression is possible due to the excess of information in the source-text and it does not distort the tasks of communication. It results in some semantical transformations: the lexical-semantical structure is reduced, and the semantical-syntactical structure is simplified.

Interpreters are constantly trained. Special syllabuses, methodological approaches facilitate interpreters' training. Assignments are aimed at further development of interpreting skills, enhancing erudition through exercises, texts for translation, talks on relevant topics, comments on intercultural communication, practical tips and the like. According to Popova (2014), "The verbalization of intention in pre-election discourse and in any other discourse and syntagmatic construction demand from addressee the knowledge of paradigmatic peculiarities of the given language system" (p. 52). The high quality of translation derives much from the deep background knowledge of trainees, their efficiency in the interlinguistic and intercultural thesaurus. Much should be done here by contrastive analysis of original and target texts, by the search for differences and similarities in linguistic and cultural paradigms.

Efficiently goes the process with aspect word-translation (I) and text translation (II).

Quick solutions to challenges are naturally acquired and developed through the relevant set of exercises (I):

- find words in the text which mean the opposite of joy;

- find synonyms for navigability;

- how would you translate the following words into Ukrainian;

- complete set expressions with suitable words;

- make sure you have dictionaries and available sources;

- make back translation, compare versions and discuss differences;

- translate the following sentences into Ukrainian;

- translate the following English units adequately;

- pick out cases of equivalents (partial, complete, zero) and translation loans;

- identify the communicative equivalents;

- enlarge the list of antonyms;

- identify the cases of generalization, concretization;

- translate and retell the jokes;

- explain the use or the absence of articles before the italicized words;

- translate the following sentences paying special attention to the use of the words.

A translator should train craftsmanship through developing skills of text comprehension, of overcoming linguistic shock, attention span. Robinson (2004) claimed, "The translator too must be reliable. A sensitive and versatile translator will recognize when a given task requires something besides straight "accuracy" - various forms of summary or commentary or adaptation, various kinds of imaginative re-creation" (p. 11).

Dealing with texts as the highest communicative units, translators should keep in mind the major categories of text (specific features of a particular text) and intertextuality (typological features of any text).

Prerogatives are text assignments of the type (II):

- read the text and answer the questions;

- dramatize the episodes; title major situations of the article;

- do a formal two-way translation of a talk; read the text, and try to sum it up (in one sentence if possible) the two or three main points; 
- explain in one sentence what happens to people who participate in the episode, in encounter groups;

- sum up and translate what the writer has said by a cluster of 100 words;

- put down the text in universal translator's notation;

- do a sight translation of the article; develop a web page or blog with own translated words;

- participate in online forums;

- estimate the translation software / webpages and report them back to the group.

Conclusions. Language works wonders. We do a lot of things with a language: we report an accident, express our emotions, give shape to our experiences, translate a passage, describe creative efforts, we train future professionals, we broaden the horizons of people, we draw of picture of linguacognitive vision of the world, we bring together people of different nations. An interpreter is able to communicate with people of another culture if he is aware of both language and culture idiosyncrasy. We shed light on the structural, compositional, stylistical means of expressing target informative and pragmatic values of the original texts. The problems of translatology have been long discussed, yet they are far from being solved. The ideas touched upon in this paper are open to further discussions. A complex approach to the translatology offers further prospects and discussions. Adequate strategies and tactics are needed to meet the growing requirements of the scientific worldview. Trainees are to pass a thorny path of syncreta - integrity of lingual and translation approaches to become genuine professionals.

The wide range of know-how questions determines translatology relevance to the modern linguistics. Prospective vistas for further investigation include, in particular, the phenomena of domestication and foreignization. Domestication is based on an analogy as the simplest way of connection between cultures. Foreignization consists in the elimination of differences between cultures. Translators have to make their own decisions what strategy and tactics to resort to. The professional competence of translators is being constantly developed. The following dimension model works with translatology strategy, tactics, methods and ways of rendering. It is claimed that a translator should study and analyze the cultural concepts of the source text, explore the ways they are presented at the pre-translation stage and then determine the set of strategies and tactics for adequate reproduction of the concepts.

\section{References:}

Benson, Ph. (2013). Teaching and Researching: Autonomy in Language Learning Applied linguistics in Action. London and New York: Routledge. http://dx.doi.org/10.4324/9781315833767

Karaban, V. I. (2004). Pereklad angliyskoi naukovoyi i tekhnich noyi literatury. Leksychni, terminologichni ta zhanrovostylistychni trudnoshchi [Translation of English scientific and technical literature. Grammatical difficulties, lexical, terminological and genre-stylistic problems]. Vinnytsia, Ukraine: Nova knyga.

Niedzielski, H.Z. \& Chernovaty, L. M. (1993). Linguistic and Technical Preparation in the Training of Technical Translators and Interpreters. In S. E. Wright \& L. D. Wright Jr.Scientific (Eds.) Technical Translation [American Translators Association Scholarly Monograph Series VI] (pp.123-149). Amsterdam, the Netherlands: John Benjamins PC http://dx.doi.org/10.1075/ata.vi.11nie

Popova, Y.V., Yemelyanova, Y.V., Prikhodko, N.A. (2014). Grammatical and Lexical Constituents of Pre-Election Discourse. Middle-East Journal of Scientific Research, 19 (1), 48-51. http://dx.doi.org/10.5829/idosi.mejsr.2014.19.1.12484

Rebrii O.V. (2013). Constraints to Creativity in Translation. The Advanced Science, 1, 42-45.

Robinson, D (2004). Becoming a Translator: An Introduction to the Theory and Practice of Translation. London and New York: Routledge. http://dx.doi.org/10.4324/9780203425961

Pym, An. (2014). Translating between languages. Routledge Handbook of Linguistics. London and New York: Routledge. Retrieved from: http://usuaris.tinet.cat/apym/on-line/translation/2014 translating between_languages.pdf

Shuttleworth, M., Cowie, M. (2014). Dictionary of Translation Studies. London and New York: Routledge.

Shvachko, S. O. (2015). Teaching to Translation. Sumy: Sumy State University. Retrieved from: http://essuir.sumdu.edu.ua/bitstream/123456789/42327/1/pereklad.pdf 